\title{
Assessment the Role of Sediment in the Sumber Brantas Rivers Watershed Affected by Agroforestry Activities
}

\author{
Barlah Rumhayati ${ }^{1}$, Hari Siswoyo ${ }^{2}$, and MH. Chusnuddin Nurochman ${ }^{1}$
}

\begin{abstract}
Assessment the role of sediment in the Sumber Brantas River watershed has been conducted in Sumber Brantas, Bumiaji, Batu. The area has been affected by agroforestry activities. The assessment was focused to the availability of nutrients (phosphorous and nitrogen compounds) and metals in sediment and water column. Water and sediment samples were collected from outlet Sumber Brantas watershed in Arboretrum, Sumber Brantas, Bumiaji, Batu, Malang in July 2013. Assessment of physical and chemical water properties included $\mathrm{pH}$, conductivity, temperature, TDS, DO, COD, total $P$ and reactive $P$, nitrate and ammonia, dissolved metals ( $\mathrm{Al}, \mathrm{Fe}, \mathrm{Mn}, \mathrm{Ca}, \mathrm{Mg})$. Meanwhile, the assessment of physical and chemical properties of sediment included texture, porosity, density, $\mathrm{pH}$, redox potensial, DO, organic matter, $N$ and $P$ sediment solution, total metals, and exchangeable metals. Results showed that water body of Sumber Brantas watershed was oxic. The level of nitrate in wPater bodies was higher than ammonia level due to nitrification process while the level of FRP was low. Most of P in the water bodies were adsorbed onto oxide/hydroxide metals and bound to metals. The sediment was at anoxic condition. The immediately pool of $P$ was lower than the potential $P$ pools. The level order of sedimentary inorganic $P$ in the sediment was residual-P $>H C l-P>$ $\mathrm{BD}-\mathrm{P}>\mathrm{NaOH}-\mathrm{P}>\mathrm{NH} 4 \mathrm{Cl}-\mathrm{P}$. Although the level of $\mathrm{DO}$ in sediment was low so that the denitrification was occurred but the $P$ could not easily released from the $\mathrm{FeOOH}$ surface. The complex of $\mathrm{FeOOH}-\mathrm{P}$ in sediment was stable to be dissociated so $P$ was not released into water bodies even under anoxic condition. Therefore, the role of sediment of the Sumber Brantas River watershed was as a for P compounds while nitrate in the sediment was subjected to change and equilibrate with ammonia.
\end{abstract}

Keywords — sediment, watershed, water column, nutrients, exchangeable metals, agroforestry.

\section{INTRODUCTION}

S mber Brantas watershed is part of Brantas watershed, the biggest watershed in East Java province, Indonesia. In 2003, the Sumber Brantas watershed area was $43,529.23$ hectare $(42.81 \%$ of Brantas watershed area). The water was used as drinking water source, power plant based water, industry, irrigation, and fisheries [1]. However, there are land use changes in Sumber Brantas watershed for many years which decrease of water quality. Agroforestry has been introduced to farmers in the area by planting perennials which will hold soil. As a result, erosion could be minimizing so the quality of water in watershed, specially the concentration of phosphorus, nitrogen compounds, and total suspended solid, will be increased. However, water quality in the watershed is not only determined by the agroforestry itself. Sediments below the water has potential role either as a source or as a sink of nutrients.

Availability of phosphorous (phosphate) for algae in the water body is determined by the fractions of phosphate in sediment. Whilst, the fractions of phosphate in sediments are determined by the physical and chemical properties of sediments, such as texture, porosity, $\mathrm{pH}$, DO, potential redox, nitrate concentration, total metals concentration, concentration of exchangeable metals of $\mathrm{Al}, \mathrm{Fe}, \mathrm{Mn}, \mathrm{Ca}$, and $\mathrm{Mg}[2,3]$. Methods of sequential extraction have been published to determine fractions of phosphorus [3-5].

'Barlah Rumhayati and MH. Chusnuddin Nurochman are with Departement of Chemistry, Faculty of Engineering, Universitas Brawijaya, Malang, Indonesia. E-mail: rumhayati_barlah@ub.ac.id; Chusnudin MH@yahoo.com.

${ }^{2}$ Hari Siswoyo is with Departement of Water Resources Engineering, Faculty of Engineering, Universitas Brawijaya, Malang, Indonesia. Email: hari_siswoyo@yahoo.com.
The aim of this research was to assess the role of Sumber Brantas watershed sediment for the availability of phosphorus compounds in water bodies.

\section{METHOD}

\section{A. Location and time of sampling}

Water and sediment samples were collected from the outlet of Sumber Brantas watershed in Sumber Brantas village, Bumiaji, Batu, Malang, East Java (Fig.1). Samples were taken from five sampling point at coordinate of $07^{\circ} 45,422^{\prime}, \mathrm{S}, \quad 112^{\circ} 31,640^{\prime}$ E (I); $07^{\circ} 45,440^{\prime} \quad \mathrm{S}, \quad 112^{\circ} 31,629^{\prime}$ E (II); $07^{\circ} 45,433^{\prime}$ S, $112^{\circ} 31,630^{\prime} \mathrm{E}$ (III), $07^{\circ} 45,430^{\prime} \mathrm{S}, 112^{\circ} 31,635^{\prime} \mathrm{E}$ (IV); and $07^{\circ} 45,424^{\prime} \mathrm{S}, 112^{\circ} 31,639^{\prime} \mathrm{E}$. These locations were about $1 \mathrm{~km}$ from the Spring of Brantas River. Sampling was conducted in July 2013 at the end of dry season in East Java.

\section{B. Samples handling}

At each sampling point, two sediment and water samples were collected and placed in the appropriate sample containers. Water samples were collected using water collector. Some water samples were subjected to filtrate using cellulose nitrate syringe filter $(0.45 \mu \mathrm{m}$ pore size) before preservation. Concentrated nitric acid was used to preserve water samples for metals analysis while sulphuric acid $0.25 \mathrm{M}$ was used to preserve water samples for phosphate analysis. The physical and chemical properties of water were determined, i.e. temperature, conductivity, total dissolved solid,(TDS), $\mathrm{pH}$, concentration of dissolved oxygen (DO), filterable reactive phosphate (FRP), nitrate, ammonia, dissolved metals of $\mathrm{Al}, \mathrm{Fe}, \mathrm{Mn}, \mathrm{Ca}, \mathrm{Mg}$.

The outlet of Sumber Brantas watershed is shallow with creek width is approximately $2.5 \mathrm{~m}$. Therefore, sediment samples were collected using plastic scope. Next, the samples were placed in a black plastic bag. The 
physical and chemical properties of sediment analyzed were density, porosity, texture, redox potential, $\mathrm{pH}$, DO, water content, organic matter, phosphate fractions, and nutrients in pore water (FRP, nitrate, and ammonia).

Water and sediment samples were stored in cool box during travelling back to laboratory. The samples were analyzed as soon as possible when arrived.

\section{Chemical analysis}

For analyzing physical and chemical properties of water and sediment samples used standard analysis method. Fractionation of phosphorus in sediment was used sequential extraction adopted from [4]. The fractions were $\mathrm{NH}_{4} \mathrm{Cl}-\mathrm{P}$, buffered dithionite-P, $\mathrm{NaOH}-\mathrm{P}$, $\mathrm{HCl}-\mathrm{P}$, and residual-P. Phosphate and nitrate were analyzed based on visible spectrophotometric method while metals were determined using atomic absorption spectroscopy (AAS) method.

\section{RESULT AND DISCUSSION}

\section{A. Biophysic of Sumber Brantas watershed}

From the interpretation of the Digital Map of Rupa Bumi Indonesia at 1:25.000 scale published by the Survey and Mapping Coordination Agency (BAKOSURTANAL), it can be seen that the area of Watershed is $1.175 \mathrm{~km} 2$ with the length of the main stream is $2.29 \mathrm{~km}$. The land use of Sumber Brantas watershed are shown in Table 1.

From the interpretation of the soil type map from Batu and Mojokerto regency, it was known that the type of soil found throughout the watershed Sumber Brantas is Andosol gray and Regosol Grey.

Based on the biophysical properties and with low rainfall in July, it can be concluded that during sampling land erosion did not occur so that no sediment material from agroforestry activities. Thus, watershed sediment is only from the deposition of products of biological, chemical, and physical processes, as well as the primary mineral.

\section{B. Sediment Properties and Its Role}

As shown in Table 2, the sediment of Sumber Brantas watershed had sandy texture with relatively high porosity. The sediment $\mathrm{pH}$ was neutral so as no leaching of mineral metals. Low redox potential and dissolved oxygen level could affect the release of $\mathrm{P}$ fractions and nitrogen compounds.

Dissolved nitrogen compounds (nitrate and ammonia) and FRP in porewater sediment showed at low level (Fig.2). Concentration of nitrate, ammonia, and FRP from five sampling sites were 0.3846-1.4102 mg/l $(0.8718 \pm 0.4478 \mathrm{mg} / \mathrm{l}) ; 0.3456-0.8917 \mathrm{mg} / \mathrm{l}(0.5191 \pm$ $0.2335 \mathrm{mg} / \mathrm{l}) ; 0.3934-2.7742 \mathrm{mg} / \mathrm{l}(1.8118 \pm 0.9592$ $\mathrm{mg} / \mathrm{l})$, respectively. It seems that most of nitrate had denitrified to ammonia at low redox potential and DO level. Whilst, FRP concentration in porewater sediment was relatively higher than concentration of $\mathrm{N}$ compounds. These compounds could diffuse into overlying water. Because FRP porewater is immediately available $\mathrm{P}$ for algae [6], it becomes limiting nutrient for algae growth.

The FRP in porewater sediment refers to the dissolved $\mathrm{P}$ from dissolution of mineral bound $\mathrm{P}$ and desorption of $\mathrm{P}$ from hydroxide/oxide metals in sediment. These fractions of $\mathrm{P}$ compound in sediment were shown in Figure 3. NH4Cl-P fraction was ranged from 0.0084 to $0.0378 \mathrm{mg} / \mathrm{l}(0.0185 \pm 0.0122 \mathrm{mg} / \mathrm{l})$. This fraction indicates loosely bound or sorbed-P [4, 7]. This gives contribution to FRP concentration in porewater sediment so as immediately available for algae.

BD-P fraction was from 0.4637 to $1.5925 \mathrm{mg} / \mathrm{l}$ (1.0676 $\pm 0.5385 \mathrm{mg} / \mathrm{l})$. The buffered dithionite extracted the reductant soluble $\mathrm{P}$, redox-sensitive $\mathrm{P}$, i.e. $\mathrm{P}$ which is adsorbed onto $\mathrm{Fe}$ and $\mathrm{Mn}$ hydroxide [5]. The soluble reactive $\mathrm{P}$ which could be extracted using $\mathrm{NaOH} 1 \mathrm{M}$ ( $\mathrm{NaOH}-\mathrm{P}$ fraction) was metallic oxide bound $\mathrm{P}$, i.e. $\mathrm{P}$ which is bound to $\mathrm{Al}$ and $\mathrm{Fe}$ oxide. The concentration of this fraction was ranged from 0.4200-1.8040 mg/l $(0.9904 \pm 0.5948 \mathrm{mg} / \mathrm{l})$. The average concentration (in bracket) of this fraction is lower than the one of BD-P fraction. It correlates with the concentration of metals (extractable and total) in Figure 4 and 5 where the concentration of Al metal was the lowest among the Fe and $\mathrm{Mn}$ metals. The $\mathrm{NaOH}-\mathrm{P}$ fraction could estimate the short term and long term available pool $\mathrm{P}$.

It will be available for algae when anoxic conditions prevail at the interface of sediment-water [8, 9]. However, as claimed by Golterman [3], phosphate extracted with $\mathrm{NaOH}$ was very dependent on $\mathrm{NaOH}$ concentration and extraction time. $\mathrm{NaOH}$ will also extract phytate phosphate and other organic $\mathrm{P}$ as well. Therefore, more deeply study of this extraction step should be focused for further research.

The $\mathrm{HCl}$ extractable $\mathrm{P}$ refers to the carbonate bound $\mathrm{P}$ ( $\mathrm{CaCO} 3$ and $\mathrm{MgCO} 3$ ), apatite-P, and oxide dissoluble $\mathrm{P}$. It mainly consists of hydrolyzed organic P [4]. Its concentration is Sumber Brantas watershed sediment was from 3.1480 to $5.1620 \mathrm{mg} / \mathrm{l}(3.8440 \pm 0.7837 \mathrm{mg} / \mathrm{l})$. This fraction dominated the sedimentary inorganic P. It could be confirmed with the high concentration of total $\mathrm{Ca}$ in sediment.

The residual $\mathrm{P}$ fraction consisted of organic $\mathrm{P}$ and refractory $\mathrm{P}$ [4], which is $\mathrm{P}$ bound to the primary mineral P. It was ranging from 0.7560 to $7.0920 \mathrm{mg} / \mathrm{l}$ $(4.5152 \pm 2.4707 \mathrm{mg} / \mathrm{l})$. Even though this fraction has higher concentration than other four $\mathrm{P}$ fractions of inorganic sedimentary-P, residual $\mathrm{P}$ has less potential to be available for algae.

Amongst all $\mathrm{P}$ fractions, only the $\mathrm{NH} 4 \mathrm{Cl}-\mathrm{P}$ fraction which is immediately available for alga in water bodies. It was only $0.3 \%$ of all fraction. Whilts $\mathrm{BD}-\mathrm{P}, \mathrm{NaOH}-\mathrm{P}$, $\mathrm{HCl}-\mathrm{P}$, and Residual $\mathrm{P}$ are potential $\mathrm{P}$ pool. The percentage of this pool was $99.7 \%$. This $\mathrm{P}$ fraction will be available for algae when there is changing of dissolved oxygen concentration or $\mathrm{pH}$. Depleting concentration of dissolved oxygen will reduced metal hydroxide/oxide and will release the adsorbed $P$. However, when level of DO is decreased, it would be denitrification of nitrate. Golterman [3] stated that there is a strong link between $P$ in sediment and denitrification. He showed that in a swallow lake the amount of nitrate reduced is roughly equal to the amount of sulfate and $\mathrm{FeOOH}$ produced. It would be occurred in sediment of Sumber Brantas watershed. The level of DO was very low, induced the anoxic condition which causes denitrification of nitrate. Denitrification will increase $\mathrm{P}$ fixation in sediment due to the increasing of $\mathrm{FeOOH}$ concentration. Small increase of acidity due to 
denitrification process will shift the equilibrium of $\mathrm{FeOOH}-\mathrm{P}$ and $\mathrm{CaCO} 3-\mathrm{P}$ in calcerous sediment.

On the other hand, the formation of FeS due to the reduction $\mathrm{Fe}$ (III) of $\mathrm{FeOOH}$ during anoxic condition FeOOH-P complex [10]. It was due to the small reducing capacity in, such as lake, to reduce a considerable quantity of $\mathrm{FeOOH}$ present. In addition, the $\mathrm{FeOOH}-\mathrm{P}$ complex is more stable than $\mathrm{FeOOH}$ complex so as needs more energy to reduce $\mathrm{FeOOH}-\mathrm{P}$ than the excess of $\mathrm{FeOOH}$ itself.

\section{Water Bodies Quality}

The studied valve is a flat plate type, shown in Figure 3. The valve consists of four main components: valve seat, stop plate (guard), valve plate (sealing), spring. Schematically, Figure 4 shows a discharge valve seat as supplied by the vendor (manufacturer). The discharge valve seat as supplied by the vendor is called the valve seat with normal (unmodified) profile organic molecules dissolved in the water caused high level of TDS $(56.4 \pm 1.949 \mathrm{mg} / \mathrm{l}))$.

The level of DO was showed high $(7.026 \pm 0.128 \mathrm{mg} / \mathrm{l})$. Under this oxic condition, nitrification of ammonia into nitrate would be occurred. It could explain the higher level of nitrate than the ammonia itself. On the other hand, the concentration of FRP was lower than the one of nitrate $(1.159 \pm 0.745 \mathrm{~g} / \mathrm{l})$. The concentration of dissolved metals were relatively low. It could be most the metals in the form of oxide/hydroxide colloids. This colloid has high surface area to adsorp $\mathrm{P}$ and settling down sediment under water.

\section{The role of Sumber Brantas Watershed Sediment}

In the water ecosystem, the availability of compounds in water bodies-sediment interface is affected by the physical-chemical properties of water bodies and sediment. In case of Sumber Brantas watershed, the sediment was at anoxic condition while the water was at oxic condition. Especially for distribution of $\mathrm{P}$ between water-sedimen, the oxic condition of water causes a decrease of $\mathrm{P}$ level due to the adsorption of $\mathrm{P}$ compounds onto the oxidized form of metal, such as $\mathrm{Al}, \mathrm{Fe}$, and $\mathrm{Mn}$. The neutral $\mathrm{pH}$ of water will also reduce the level of $\mathrm{P}$ due to bounding of this compound on to the colloidal of oxide/hydroxide metals, such as $\mathrm{Fe}, \mathrm{Mn}, \mathrm{Ca}$, and $\mathrm{Mg}$. As a result, the concentration of $\mathrm{P}$ in water bodies of Sumber Brantas watershed was low.

When the water contact with sediment, $\mathrm{P}$ will diffuse into sediment, either dissolved in the pore water sediment; adsorbed onto the surface of oxide/hydroxide $\mathrm{Al}, \mathrm{Fe}, \mathrm{Mn}$; or bound to $\mathrm{Ca}$ and $\mathrm{Mg}$. Even though the sediment of Sumber Brantas was anoxic so that denitrification of nitrate was occurred, the oxide/hydroxide FeOOH-P was not dissociated and released $\mathrm{P}$ into water bodies. The $\mathrm{pH}$ of sediment in Sumber Brantas watershed was also not caused the dissolution of $\mathrm{Al}$ oxide/hydroxide and $\mathrm{Ca} / \mathrm{Mg}$ carbonates so that the $\mathrm{P}$ was not released from the sediment.

From this point of view, the sediment of Sumber Brantas watershed has potential role as a sink of phosphorus compounds. In case there is sediment loading from agroforestry activities, the level of $\mathrm{P}$ in water bodies will remain low, as long as there is no changing of $\mathrm{pH}$ and dissolved oxygen concentration. Meanwhile, the sediment role for nitrate could not be specified due to the equilibrium of nitrate-ammonia through nitrification-denitrification process.

\section{CONCLUSION}

The water bodies was at oxic condition. The level of nitrate in water bodies was higher than ammonia level due to nitrification of nitrate. The level of FRP in water bodies was low because of the adsorption of the compounds onto metals oxide/hydroxide and bound to metals. Meanwhile the sediment was anoxic. The rank order of $\mathrm{P}$ in sediment of Sumber Brantas watershed was Residual-P > HCl-P > BD-P > NaOH-P > NH4Cl-P. The immediate available $\mathrm{P}$ poll is lower than the potential available $\mathrm{P}$ pool. As a result, the sediment of Sumber Brantas watershed has high potential as a sink of $\mathrm{P}$ compounds.

\section{ACKNOWLEDGEMENT}

Author would like to thanks to Brawijaya University for the research funding.

\section{REFERENCES}

[1]. Anonymous, Kondisi Wilayah Daerah Aliran Sungai Brantas in Statistik BP DAS Brantas tahun 2003 2003, BP DAS Brantas.

[2]. Viaroli, P., M. Bartoli, G. Giordani, P. Magni, and D.T. Welsh, Biogeochemical Indicators as Tools for Assessing Sediment Quality/Vulnerability in Transitional Aquatic Ecosystems, Aquatic Conserv: Mar. Freshw. Ecosyst., 14, p. S19-S29, 2004.

[3]. Golterman, H.L., Fractionation and bioavailability of phosphate in lacustrine sedimen, a review, Limnetica, 20, (1), p. 15-29, 2001.

[4]. Fytianos, K. and A. Kotzakioti, Sequential Fractionaton o Phosphorus in Lase Sedimens of Norther Greece, Environ. Monitor. and Assessment, 100, p. 191-200, 2005.

[5]. Ribeiro, D.C., G. Martins, R. Nogueira, J.V. Cruz, and A.G. Brito, Phosphorus fractionation in volcanic lake sediments (Azores-Portugal), Chemosphere, 70, p. 1256-1263, 2008.

[6]. Golterman, H.L., The Labyrinth of Nutrient Cycles and Buffers in Wetlands: Results Based on Research in the Camargue (southern France), Hydrobiologia 315, p. 211-222, 1995.

[7]. Azzouz, S. and C. Boukhalfa, Fractionaton of phosphorus in surface sediments downstream of a water dam in Eastern Algeria, Procedia Engineering, 33, p. 121-125, 2012.

[8]. Zhou, Q., C. Gibson, and Y. Zhu, Evaluation of phosphorus bioavailability in sediments of three contrasting lakes in China and the U.K, Chemosphere, 42, p. 221-225, 2001.

[9]. Dorich, R., D. Nelson, and L. Sommers, Estimating phosphorus in suspended sediment by chemical extraction, J. Environ. Qual., 14, p. 400-405, 1985.

[10]. Golterman, H.L., Phosphate release from anoxic sediments, Hydrobiologia, 450, p. 99-106, 2001. 


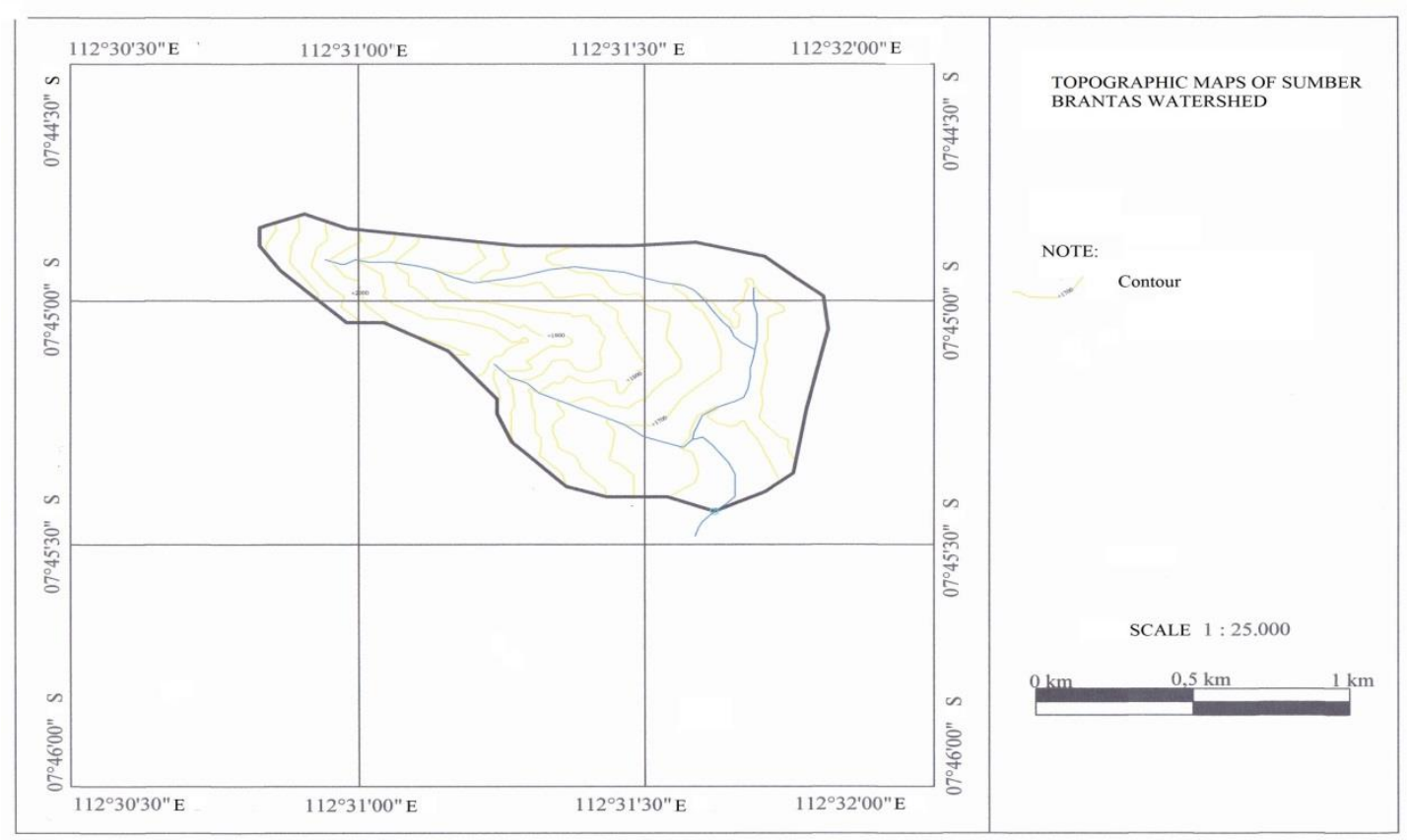

Figure 1. Topographic map of Sumber Brantas watershed. Inlet is the watershed outlet where water and sediment samples were collected

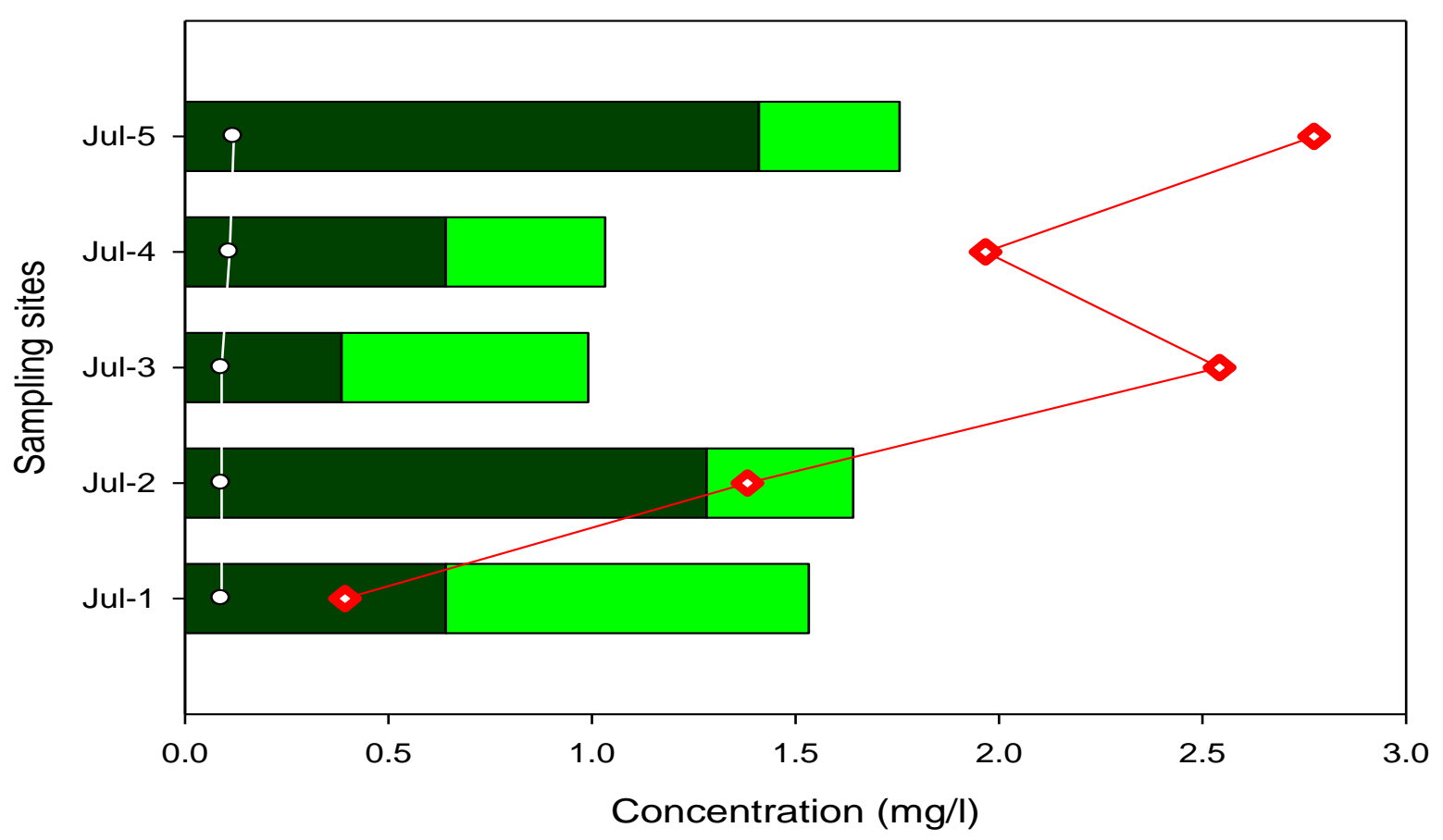

nitrate porewater

ammonia porewater

FRP porewater

- DO sedimen

Figure 2.Concentration of nitrate, ammonia, and FRP in porewater sediments with DO level 


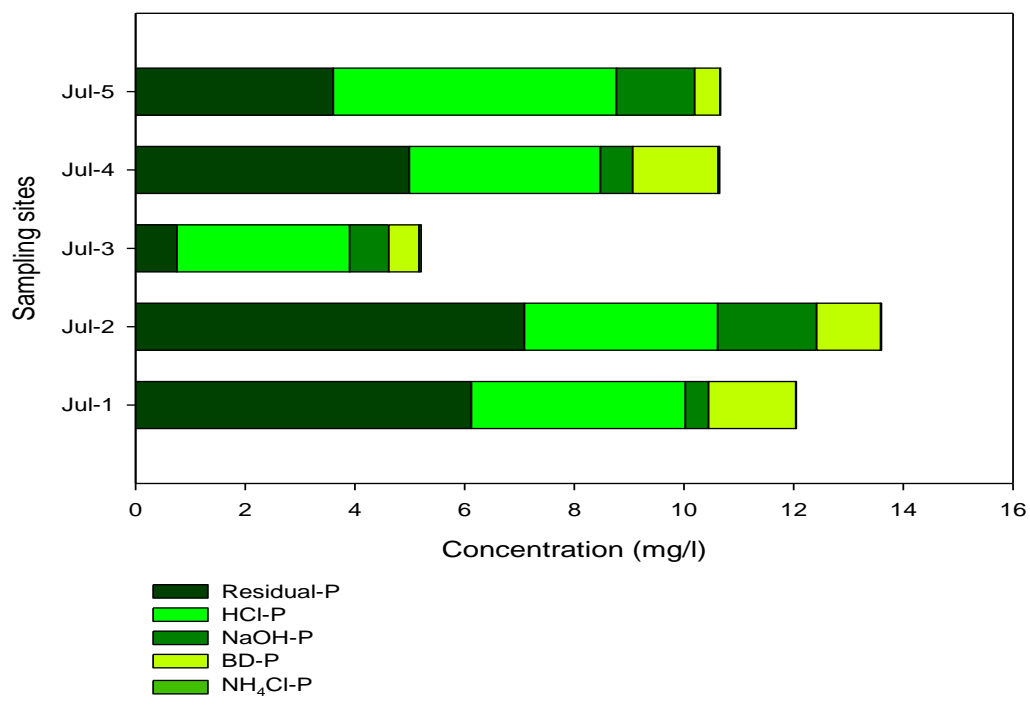

Figure 3. Fractionation of $\mathrm{P}$ compounds in sediments
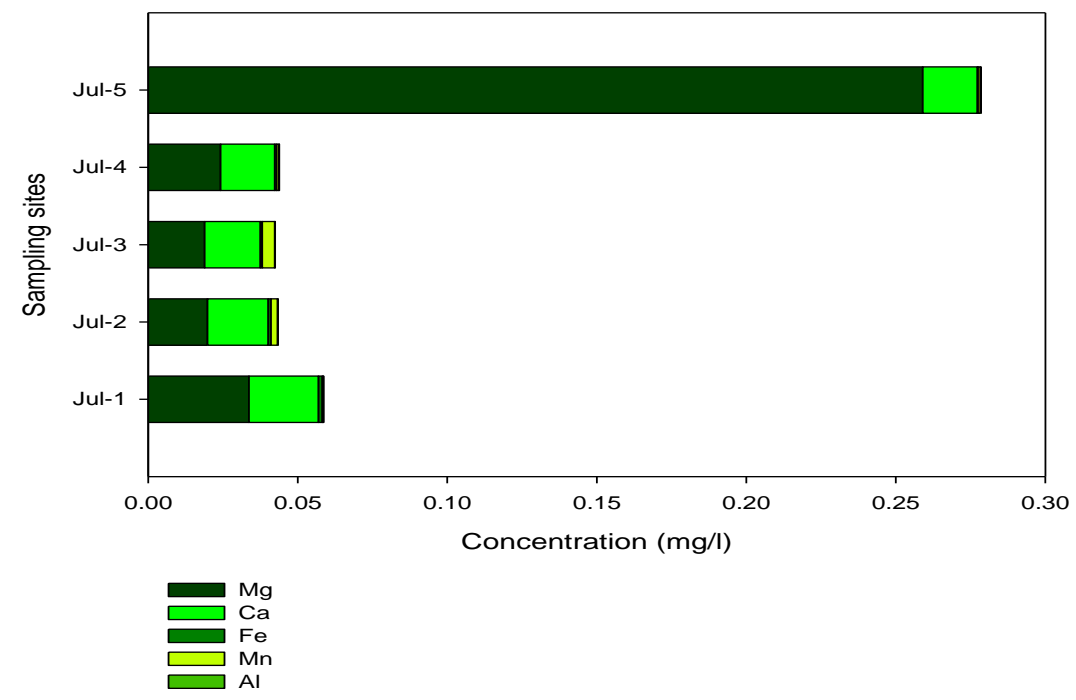

Figure 4. Extractable metals concentration in sediments

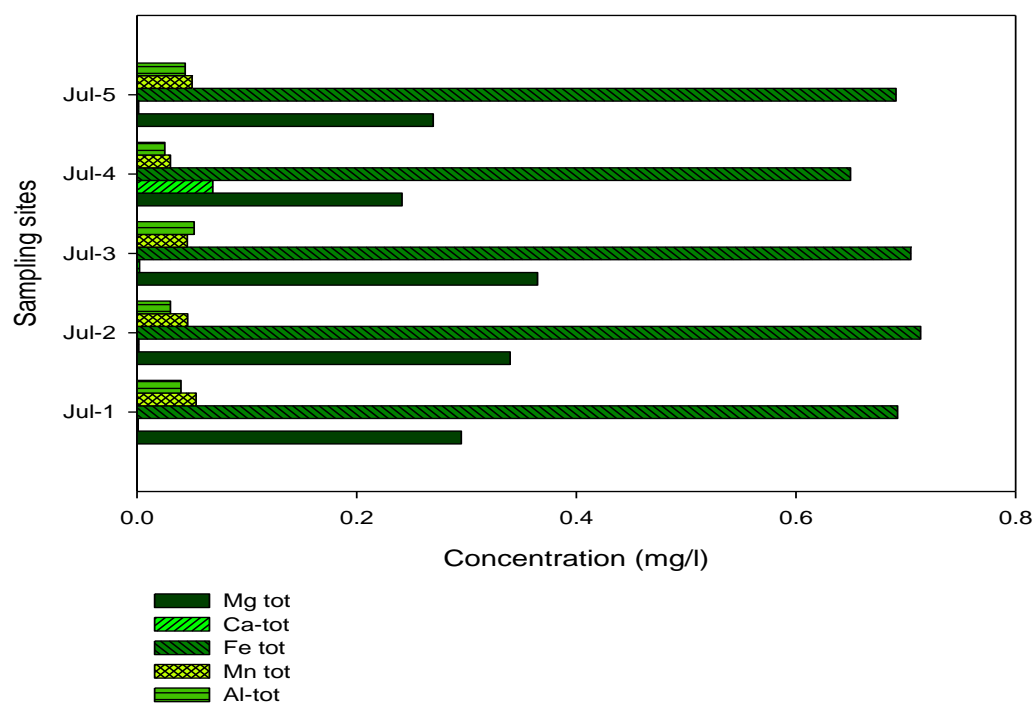

Figure 5. Total metal concentration in sediments 
TABLE 1.

THE LAND USE OF SUMBER BRANTAS WATERSHED

\begin{tabular}{ccc}
\hline \hline \multirow{2}{*}{ Land Use } & \multicolumn{2}{c}{ Area } \\
& $\mathbf{k m}^{\mathbf{2}}$ & $\mathbf{\%}$ \\
\hline Forest & 0,875 & 74,47 \\
Field & 0,146 & 12,43 \\
Bush & 0,154 & 13,10 \\
\hline Total & $\mathbf{1 , 1 7 5}$ & $\mathbf{1 0 0 , 0 0}$ \\
\hline
\end{tabular}

TABLE 2.

PHYSICAL AND CHEMICAL PROPERTIES OF SEDIMENTS OF SUMBER BRANTAS WATERSHED

\begin{tabular}{ccccccc}
\hline \hline Sampel & $\begin{array}{c}\text { Density } \\
(\mathrm{g} / \mathrm{l})\end{array}$ & $\begin{array}{c}\text { Porosity } \\
(\%)\end{array}$ & Texture & $\mathrm{pH}$ & $\begin{array}{c}\text { Redox } \\
\text { potential } \\
(\mathrm{mV})\end{array}$ & DO (ppm) \\
\hline July-1 & 2.38 & 45.09 & Sandy & 6.60 & 28.00 & 0.09 \\
July-2 & 2.71 & 41.87 & Sandy & 6.90 & 28.00 & 0.09 \\
July-3 & 2.96 & 45.86 & Sandy & 6.70 & 20.00 & 0.09 \\
July-4 & 2.32 & 39.77 & Sandy & 6.60 & 25.00 & 0.11 \\
July-5 & 2.72 & 42.26 & Sandy & 6.60 & 33.00 & 0.12 \\
\hline \hline
\end{tabular}

TABLE 3.

PHYSICAL AND CHEMICAL WATER PROPERTIES OF SUMBER BRANTAS WATERSHED

\begin{tabular}{|c|c|c|c|c|c|c|c|c|c|c|c|c|c|}
\hline Sampel & $\overline{\mathrm{pH}}$ & $\begin{array}{c}\text { DHL } \\
(\mu \mathrm{mhos})\end{array}$ & $\begin{array}{c}\text { TDS } \\
(\mathrm{ppm})\end{array}$ & $\begin{array}{c}\text { Temperature } \\
(\mathrm{oC})\end{array}$ & $\begin{array}{c}\mathrm{DO} \\
(\mathrm{mg} / \mathrm{l})\end{array}$ & $\begin{array}{l}\text { FRP } \\
(\mathrm{mg} / \mathrm{l})\end{array}$ & $\begin{array}{l}\text { Nitrate } \\
(\mathrm{mg} / \mathrm{l})\end{array}$ & $\begin{array}{c}\text { Ammonia } \\
(\mathrm{mg} / \mathrm{l})\end{array}$ & $\begin{array}{c}\mathrm{Al} \\
(\mathrm{mg} / \mathrm{l})\end{array}$ & $\begin{array}{c}\mathrm{Ca} \\
(\mathrm{mg} / \mathrm{l})\end{array}$ & $\begin{array}{c}\mathrm{Mg} \\
(\mathrm{mg} / \mathrm{l})\end{array}$ & $\begin{array}{c}\mathrm{Fe} \\
(\mathrm{mg} / \mathrm{l})\end{array}$ & $\begin{array}{c}\mathrm{Mn} \\
(\mathrm{mg} / \mathrm{l})\end{array}$ \\
\hline 1 & 6.000 & 116.000 & 54.000 & 17.000 & 7.100 & 1.638 & 6.176 & 0.130 & 0.097 & 1.083 & 7.510 & 0.043 & 0.184 \\
\hline 2 & 6.000 & 113.000 & 55.000 & 18.000 & 7.059 & 1.633 & 6.029 & 0.182 & 0.023 & 1.211 & 4.790 & 0.098 & 0.260 \\
\hline 3 & 6.000 & 101.000 & 57.000 & 16.000 & 7.182 & 0.088 & 2.647 & 0.103 & 0.032 & 1.008 & 2.890 & 0.157 & 0.788 \\
\hline 4 & 6.000 & 101.000 & 59.000 & 17.000 & 6.915 & 1.770 & 0.441 & 0.073 & 0.032 & 1.086 & 2.755 & 0.171 & 0.388 \\
\hline 5 & 7.000 & 103.000 & 57.000 & 18.000 & 6.875 & 0.667 & 2.794 & 0.112 & 0.046 & 0.936 & 3.968 & 0.198 & 0.356 \\
\hline Average & 6.200 & 106.800 & 56.400 & 17.200 & 7.026 & 1.159 & 3.618 & 0.120 & 0.046 & 1.065 & 4.383 & 0.133 & 0.395 \\
\hline Deviation & 0.447 & 7.155 & 1.949 & 0.837 & 0.128 & 0.836 & 2.453 & 0.040 & 0.030 & 0.102 & 1.936 & 0.062 & 0.234 \\
\hline
\end{tabular}

